\title{
Differential Protein Expression in Olive Tissues Due to Salt Treatments
}

\author{
J.L. García, J. Troncoso, M. Cantos and A. Troncoso \\ Instituto de Recursos Naturales y Agrobiología de Sevilla (CSIC) \\ Av Reina Mercedes 10, 41012 Sevilla (Spain).
}

Keywords: SDS-PAGE, salt stress, in vitro explants, olive, markers

\begin{abstract}
In this work, differential protein expression in olive tissues after salt treatments has been investigated. Olive clones selected in vitro according to their salt tolerance were submitted, also in vitro, to high salt concentrations.

After each treatment, the leaves and stems were collected and protein extracts of them subjected to polyacrilamide gel electrophoresis to analyse their band patterns.

Some differences were observed referring to 2 bands of approximately $24 \mathrm{kD}$ and $40 \mathrm{kD}$ which appeared in the extracts after exposition to salt.

It is discussed the possible implication of this polypeptide in the response of olive tree to salt stress and similarities with other proteins described in other plant species.
\end{abstract}

\section{INTRODUCTION}

Salt stress is a major concern in the fruit tree industry. Although olive could be considered as relatively tolerant to soil salinity, a sustanaible oliviculture would require more tolerant varieties which could, for example, be irrigated with saline waters.

For the selection of these new varieties or to test the salt tolerance of other already known varieties, it would be of great help to find specific markers associated to salt stress which could assist the selection process. Such markers would enable the acceleration and increased reliability of selection for resistance among cultivars in breeding programmes. Furthermore, these markers could be instrumental in identifying relevant genes, thus helping in the efforts of introducing stress resistant by gene transfer.

Up to date work on markers for different physiological situations in the olive tree has been scarce. Differential protein expression was reported for juvenile and mature olive tissues (García et al., 2000; García et al., 2002). In relation to stress resistance, Bartolini et al. (1994) found different protein patterns between tolerant and non tolerant clones of cv. Leccino when submitted to cold stress.

In this work we have compared the electrophoretic protein patterns of two different clones of cV Jabaluna after cultured in vitro with different concentrations of $\mathrm{NaCl}$ in seeking differential protein expression due to the salt treatments.

\section{MATERIAL AND METHODS}

Two clones of olive cV Jabaluna were used as plant material. These 2 clones (J0 and J79) were obtained by in vitro germination of isolated embryos as described elsewhere (Acebedo et al., 1997). Clone J0 was obtained from an embryo germinated in normal medium without salt while clone J79 was obtained from an embryo grown on 120 $\mathrm{mM}$ of $\mathrm{NaCl}$, then this was considered as tolerant. After germination, the plantlets selected were subcultured to attain enough plant material of each clone. To check the tolerance to salt of both clones, explants from them were cultivated for 7 weeks on medium $\mathrm{OM}+15$ g. $\mathrm{l}^{-1}$ of mannitol and 1 g. $\mathrm{l}^{-1}$ zeatine as base medium and 3 different treatments: control (no salt added), $50 \mathrm{mM}$, and $90 \mathrm{mM}$ of $\mathrm{NaCl}$. Single node explants of 
each clone were placed individually in test tubes with $10 \mathrm{ml}$ of media and grown in a culture chamber at $23 \pm 2{ }^{\circ} \mathrm{C}$ with a $16 \mathrm{~h}$ photoperiod and $30 \mu \mathrm{mol} \mathrm{m} \mathrm{s}^{-1}$ of light intensity.

After culture, total $n^{\circ}$ of nodes and shoot length was measured. Leaves and stems of each treatment and clone were grounded separately in liquid nitrogen and stored at -80 ${ }^{\circ} \mathrm{C}$ until use. Protein extraction was performed as described previously (García et al., 2000) and protein concentration of the extracts according to Bradford (1976).

Samples of each extract with equal amounts of protein (30 $\mu \mathrm{g})$ were subjected to SDS-polyacrilamide gel electrophoresis on $12 \%$ running and $4 \%$ stacking gels (Laemmli, 1970). Electrophoresis was carried out at $15 \mathrm{~mA}$. After running, gels were stained with $0.25 \%$ Coomassie brilliant blue and then destained. The molecular mass of the protein bands was determined by comparison with reference proteins ranging from 14.4 to 116.3 $\mathrm{kD}$ (Bio-Rad).

\section{RESULTS AND DISCUSSION}

Table 1 shows the growth of the explants of both clones after 7 weeks of culture with the different treatments. As shown in the Table, $50 \mathrm{mM}$ of $\mathrm{NaCl}$ provoked an inhibition of both the number of nodes and shoot length in both clones as compared to the control treatments. However, survival was lower for clone J0 and the shoot length was half of the clone J79. When $90 \mathrm{mM}$ of salt was applied to the medium all the explants of J0 died while those of J79 presented a 69\% of survival and some growth. This confirmed the previous supposition of J79 as more tolerant to salt.

From the examination of the electrophoretic patterns (Fig. 1) it was observed that 2 bands appeared to respond differentially to the salt treatments, since they presented more signal in the extracts corresponding to salt treated samples compared to control. One of these bands, of around $40 \mathrm{kD}$, was more strongly expressed in the stem extracts of J79 plantlets grown on 50 and $90 \mathrm{mM}$ (Fig. 1b, lanes 4 and 5) and seemed to show increasing signal with the increasing concentrations of salt which may indicate a linear response to the salt dose. The other band of around $20 \mathrm{kD}$ also seemed to increase its expression after salt exposure, both in leaves (Fig.1a, lanes 3-5) and stems (Fig.1b, lanes 3-5) of the J79 clone. In the extracts of clone J0 this behaviour was less marked. In this clone, the band of $40 \mathrm{kD}$ showed a slight increase in expression between the control and the $50 \mathrm{mM}$ stem extracts (Fig. 1b, lanes 1-2), while the $20 \mathrm{kD}$ band displayed only a faint signal in the extracts of both tissues of this clone (Fig. 1). As shown from the data of culture (Table 1), clone J79 was more tolerant to salt in vitro, so these bands may be related to the physiological and adaptative responses to salt stress and markers for the tolerance to this kind of stress. This hypothesis would be consistent with the fact of the higher expression of the polypeptides in the tissues of the more tolerant clone J79. If so, this would be the first time, up to our knowledge, in describing polypeptides related to salt stress in olive tissues, although more work is needed to confirm these results in different olive varieties and culture conditions.

The $20 \mathrm{kD}$ band shows similar characteristics of the product of the gene TAS14 that has been characterised in tomato (Godoy et al., 1990). TAS14 is inducible in tomato upon salt stress and ABA treatment, and although the predicted molecular mass for this polypeptide is $14 \mathrm{kD}$ the observed electrophoretic mobility is around $20 \mathrm{kD}$ (Godoy et al., 1990). TAS14 is a member of a general class of genes named dehydrins (dehydrationinduced). Dehydrins have been found in different plant species and are induced by ABA and different kinds of environmental stresses, including desiccation, osmotic stress and salt stress. As mentioned above, TAS14 is induced in tomato seedlings and mature plants 
upon treatment with $\mathrm{NaCl}, \mathrm{ABA}$ or mannitol and localized in stems and leaves of salt treated tomato plants (Godoy et al., 1994).

The $20 \mathrm{kD}$ band observed in the extracts of olive tissues seems to be induced by the salt treatment and its electrophoretic mobility is very close to that described for TAS14. Then, that band would be a good candidate to be a dehydrin in the olive although further investigation is needed to check this hypothesis as well as to characterize also the $40 \mathrm{kD}$ band.

\section{References}

Acebedo M.M., Lavee S., Liñán J. and Troncoso A. 1997. In vitro germination of embryos for speeding up seedling development in olive breeding programmes. Sci. Hort., 69: 207- 215.

Bartolini G., Petruccelli R., Toponi M. and Di Monte G. 1994. Morphological and biochemical evaluation of Olea europaea L. cv. Leccino. Acta Hortic., 356:78-81.

Bradford M.M. 1976. A rapid and sensitive method for the quantitation of microgram quantities of protein utilizing the principle of protein-dye binding. Anal. Biochem., 72:248-254.

García J.L., Avidan N., Troncoso A., Sarmiento R. and Lavee S. 2000. Possible juvenilerelated proteins in olive tree tissues. Sci. Hort., 85:271-284.

García J.L., Sarmiento R. and Troncoso A. 2002. Some biochemical differences between juvenile and young olive plant material. Acta Hortic., 586:537-540.

Godoy J.A., Luna R., Torres-Schumann S., Moreno J., Rodrigo R.M. and Pintor-Toro J.A. 1994. Expression, tissue distribution and subcellular localization of dehydrin TAS14 in salt-stressed tomato plants. Plant Mol. Biol., 26:1921-1934.

Godoy J.A., Pardo J.M. and Pintor-Toro J.A. 1990. A tomato cDNA inducible by salt stress and abscisic acid: nucleotide sequence and expression pattern. Plant Mol. Biol., 15:695-705.

Laemmli U.K. 1970. Cleavage of structural proteins during the assembly of the head of bacteriophage T4. Nature, 227:680-685. 
Table 1. Explant growth after 7 weeks of culture with the different salt treatments.

\begin{tabular}{|c|c|c|c|c|c|c|}
\hline Clone & \multicolumn{3}{|c|}{ J0 } & \multicolumn{3}{|c|}{ J79 } \\
\hline Treatment & $\begin{array}{c}\text { Surv. } \\
\%\end{array}$ & $\begin{array}{l}\mathrm{N}^{\circ} \text { of } \\
\text { nodes }\end{array}$ & $\begin{array}{l}\text { Shoot length } \\
(\mathrm{mm})\end{array}$ & $\begin{array}{c}\text { Surv. } \\
\%\end{array}$ & $\mathrm{~N}^{\circ}$ of nodes & $\begin{array}{l}\text { Shoot length } \\
\text { (mm) }\end{array}$ \\
\hline Control & 100 & $7.95 \pm 0.31$ & $40.05 \pm 1.91$ & 100 & $7.43 \pm 0.20$ & $58.28 \pm 1.54$ \\
\hline $50 \mathrm{mM}$ & 72.7 & $4.81 \pm 0.34$ & $16.69 \pm 1.30$ & 96.7 & $4.73 \pm 0.25$ & $30.96 \pm 1.46$ \\
\hline $90 \mathrm{mM}$ & 0 & - & - & 69.2 & $3.55 \pm 0.33$ & $16.09 \pm 2.62$ \\
\hline
\end{tabular}

a) leaves

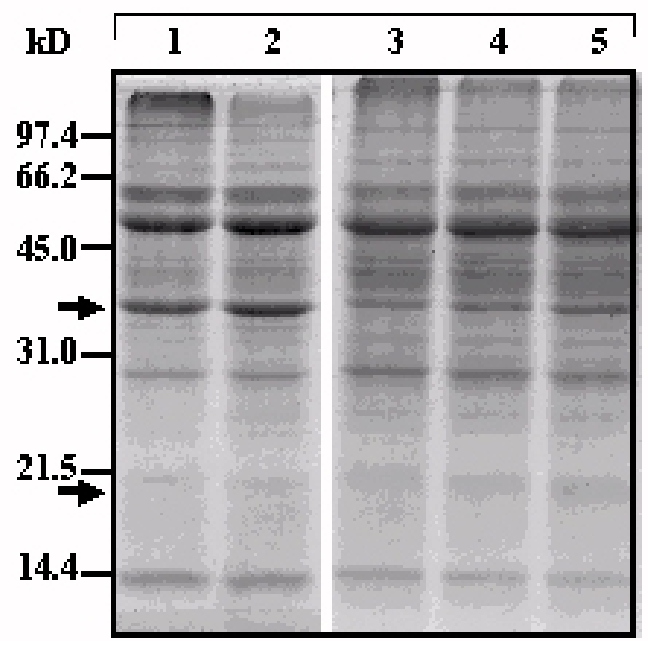

b) stem s

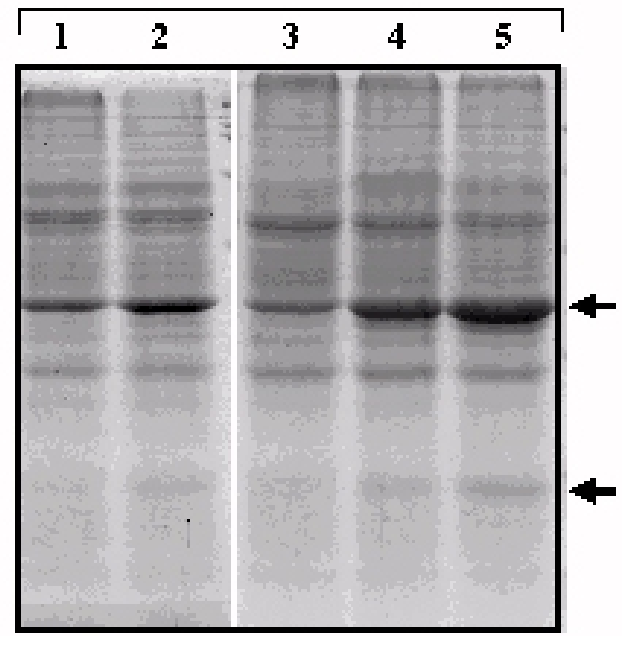

Figure 1. Electrophretic patterns of leaves and stems extracts of the explants.

a) Leaves: clone J0 control (1), clone J0 cultured in $50 \mathrm{mM}$ of salt (2), clone J79 control (3), clone J79 $50 \mathrm{mM}$ of salt (4), and clone J79 $90 \mathrm{mM}$ of salt (5).

b) Stems: clone J0 control (1), clone J0 cultured in $50 \mathrm{mM}$ of salt (2), clone J79 control (3), clone J79 $50 \mathrm{mM}$ of salt (4), and clone J79 $90 \mathrm{mM}$ of salt (5).

Arrows indicate the 40 and $20 \mathrm{kD}$ bands that show different expression in controls and in salt treated explants.

A $12 \%$ acrylamide running gels were used and $30 \mu \mathrm{g}$ of protein of each sample loaded onto the gels. 